\title{
FOUR NEW SPECIES OF CULEX.
}

BY D. W. COQUilletT, WASHiNGTON, D. C.

Culex cantator, new species.-Female. Near sylzestris, but the seventh abdominal segment almost wholly yellow scaled, etc. Head black, oral margin and base of antennæ yeliow, remainder of antennæ and the proboscis black, palpi brown, its scales chiefly concolorous, no cluster of white hairs or scales at their apices; narrow scales of middle of occiput golden yellow, the upright ones chiefly black, sides of occiput covered with depressed whitish scales and with a small cluster of black ones; thorax reddish brown, scales of mesonotum golden yellow, becoming pale yellow in front of the scutellum and on the pleura ; abdomen black, its scales black, except a crossband of yellowish white ones at base of each segment, the bands considerably narrowed at the middle, similar scales scattered over the sixth and nearly the whole of the seventh segment and along apices of the two preceding segments; legs yellow basally, becoming brown on the tibiæ and tarsi, scales of femora chiefly pale yellow, of the tibix mostly black, those on the hind side pale yellow, on the bases of the tarsal joints whitish, those on the second joint of the hind tarsi covering about one-fourth the length of the joint, front tarsal claws toothed; wings hyaline, lateral scales of the veins long and narrow, hind crossvein nearly its length from the small crossvein, petiole of first submarginal cell from one-half to four-fifths as long as the cell; length, $4 \mathrm{~mm}$. One specimen bred May 6, by Mr. LaRue Holmes.

Habitat.-Summit, New Jersey.

I have also examined 8 females and as many males, bred by Prof. J. B. Smith, from the salt-marshes of New Jersey. In the male the scales of the palpi are black, those of the under side and at bases of the last two joints yellowish white, no whitish band at base of the antepenult joint.

Prof. Smith informs me that the larva is readily separated from that of sylvestris.

Culcx aurifer, new species.-Female. Near triseriatus, but the scales on sides of mesonotum golden yellow instead of white, and the venter is without crossbands of black scales. Black, the halteres, coxæ and femora largely yellow; scales and hairs of palpi brown, scales of occiput golden yellow, the upright ones brown ; scales in middle of mesonotum brownish black, those on the sides and many in front of the scutellum golden yeliow, those of pleura pale yellow; scales of abdomen black, those on the venter pale yellow, sometimes encroaching a trifle on the dorsum, 
hairs of the first segment and at the apices of the others pale yellow; scales of femora and on posterior side of tibiæ pale yellow, remaining scales of tibiæe and those on the tarsi black, front tarsal claws toothed; wings hyaline, lateral scales of the veins long and narrow, hind crossvein about its length from the small crossvein, petiole of first submarginal cell three-fifths the length of the cell; length, $4.5 \mathrm{~mm}$.

Three specimens, collected June 22 and 25 , by Dr. H. G. Dyar.

Habitat.-Centre Harbour, N. H.

I have also examined two males and two females from Lahaway, $\mathrm{N}$. J., bred by Dr. J. B. Smith, who writes that the larva is very different from that of triseriatus. The adult male is similar to the female except that the hairs of the palpi are chiefly whitish, and the dorsum of the abdomen has several yellow scales on the apical half.

Culex nanus, new species.-Female. Near jamaicensis, but much smaller, the light-coloured scales on the tibiæ not collected into spots, mesonotum without round spots of yellowish scales, etc. Black, the base of the artenma except the first joint, a band at middle of proboscis, the halteres and bases of femora yellow; scales and hairs of palpi black, appressed scales of occiput golden yellow, the upriyht ones black, scales of mesonotum golden yellow, those of the abdomen black and with a broad crossband of whitish ones on the hiud margin of each segment, the last two segments nearly wholly whitish scaled; scales of venter white, those of femora and tibire mixed black and whitish, the latter forming a ring near three-fourths the length of each femur, scales of tarsi black, those at narrow bases of the joints whitish, tarsal claws simple; wings hyaline, the scales mixed black and white, the black ones not collected into spots, lateral scales of the anterior veins narrowly lanceolate, those of the other veins almost linear; length, $3 \mathrm{~mm}$ Four specimens collected at Key West, Florida, in August, 190r, by Mr. August Blisck, and six by Mr. E. A. Schwarz, April i to 3 , I903.

Type.-No. 6893, U. S. National Museum.

Calex discolor, new species.--Female. Differs flom the above description of nanus as follows: palpi with a cluster of white scales at the apices, upright scales of occiput yellow, whitish crossbands of abdomen prolonged forward in the middle, crossing or almost crossing the segments, scales on posterior side of front and middle tibix and on anterior side of the hind ones almost wholly pale yellow, first tarsal joint bearing many yellow scales, black and yellow scales of wings not evenly distributed, the 
black ones forming a distinct spot at forking of the second vein with the third, another on upper branch of fifth vein at the hind crossvein, and a third on the apical third of the last vein, remaining scales of this vein wholly yellow; length $4 \mathrm{~mm}$. A specimen from Delair, New Jersey, received from Prof. J. B. Smith.

Type.-No. 6894, U. S. National Museum.

\section{CORRECTIONS ANU NOTES ON DR. DYAR'S LIST OF} NOCTUIDS.-II.

BY A. RADCLIFEE GROTE, HILDESHEIM, GERMANY.

Page 99. Apatela. As might have been expected from the inconspicuous markings and uniform gray colour of the moths, the identifications of species of Acronycta, described by Walker and Guenée, have proved difficult and often contradictory. I am now inclined to waive all objections and accept Dr. Dyar's list as it stands. The only point I make is, the difficulty I have in believing that, having identified xyliniformis, Guen., already and originally for Riley, I should have redescribed specimens at a later period as pallidicoma; it seems to me yet possible that two forms are here "nixed up," although I know xyluniformis to be inconstant.

Io6. Fragilis having been transferred to Apatela, diphteroides becomes type of Microcoelia. Guenée writes Diphtera, following Ochsenheimer. Hübner originally wrote Diphthera, which is the correct Greek form.

I07. The generic term should read "Cyathissa," not "Cyathisa."

I 2. This genus should be called Monodes, Guen., type nucicolora (r. nucicolor); the type of Oligia being strigizis.

I 13. Crasia, Auriv., I89r, Staud. and Rebel, 295, is a synonym of Hillia, Grote, 1883 . According to the European catalogue iris, Zett., is an older name for the variable species.

12r. The genus is "Momaphana," not "Momophana."

I20. No. 1267. The name illepida should be preferred, since the type of diversilineata had patched wings and the species is irrecognizable from this description, and the identification of the type uncertain.

124. As I have shown in these pages, the citation to Pseudanarta of Hy. Edwards is spurious. There is no such name in Proc. Cal. Acad. Sci., Pac. Coast, Lep., Nos. I to 22. 